\title{
Investigation on Composition, Mechanical Properties, and Corrosion Resistance of Mg-0.5Ca-X(Sr, Zr, Sn) Biological Alloy
}

\author{
Yichang Su, ${ }^{1}$ Jixing Lin, ${ }^{1}$ Yingchao Su, ${ }^{1}$ Wei Zai, ${ }^{1}$ Guangyu Li $\mathbb{D}^{1},{ }^{1}$ and Cuie Wen $\mathbb{D}^{2}$ \\ ${ }^{1}$ Key Laboratory of Automobile Materials, Ministry of Education, College of Materials Science and Engineering, \\ Jilin University, Changchun 130025, China \\ ${ }^{2}$ School of Engineering, RMIT University, Melbourne, VIC 3001, Australia
}

Correspondence should be addressed to Guangyu Li; guangyu@jlu.edu.cn and Cuie Wen; cuie.wen@rmit.edu.au

Received 14 August 2017; Revised 7 November 2017; Accepted 3 December 2017; Published 23 April 2018

Academic Editor: Ying Zhao

Copyright (C) 2018 Yichang Su et al. This is an open access article distributed under the Creative Commons Attribution License, which permits unrestricted use, distribution, and reproduction in any medium, provided the original work is properly cited.

\begin{abstract}
Four nontoxic biological alloys, Mg-0.5Ca-1Sr-4Zr (Alloy 1), Mg-0.5Ca-1Sr-1.5Zr (Alloy 2), Mg-0.5Ca-3Sr-1.5Zr (Alloy 3), and Mg$0.5 \mathrm{Ca}-1 \mathrm{Sr}-0.5 \mathrm{Sn}$ (Alloy 4 ), were prepared by vacuum smelting, gravity casting, and hot rolling. The composition and microstructure of the alloys were investigated by optical microscope, X-ray fluorescence spectrometer (XRF), X-ray diffraction (XRD), scanning electron microscope (SEM), and energy dispersion spectroscopy (EDS). The mechanical properties and corrosion behaviors of the alloys in Hank's solution were studied. Results showed that a large amount of fine and uniformly distributed second-phase particles ( $\mathrm{Zr}, \mathrm{Mg}_{17} \mathrm{Sr}_{2}$, and $\mathrm{CaMgSn}$ ) was observed in four alloys obtained after rolling and alloying. The segregation of $\mathrm{Zr}$ in alloys was observed in EDS image, and chemical analysis showed that there was macrosegregation of the elements in the alloys. Furthermore, $\mathrm{Mg}_{17} \mathrm{Sr}_{2}$ phases in the Mg-0.5Ca-1Sr-0.5Sn alloy homogenized the distribution of CaMgZn phases. The comprehensive mechanical properties of four newly designed rolled alloys were much higher than those of pure $\mathrm{Mg}$, and the compressive strength of the alloys was more than twice as high as that of pure magnesium. The $\mathrm{Mg}-0.5 \mathrm{Ca}-1 \mathrm{Sr}-0.5 \mathrm{Sn}$ alloy released the least hydrogen in Hank's solution, which was lower than that of pure magnesium. Electrochemical test results in Hank's solution further showed that the $\mathrm{Mg}-0.5 \mathrm{Ca}-1 \mathrm{Sr}-0.5 \mathrm{Sn}$ alloy had delayed corrosion and lowest $I_{\text {corr }}$ which was $25 \%$ of that of pure magnesium. Biological experiments results showed that the $\mathrm{Mg}-0.5 \mathrm{Ca}-1 \mathrm{Sr}-0.5 \mathrm{Sn}$ alloy had better biocompatibility and optimal potential for bone substitute material.
\end{abstract}

\section{Introduction}

In recent years, titanium alloy, 316L stainless steel $[1,2]$, and cobalt-based alloys $[3,4]$ are widely used in bone substitute materials [5-7]. However, poor biocompatibility impacted 316L SS application. Its implantation into the human body may cause the occurrence of allergic reactions to nickel [8]. Ebadian et al. compared various implantation materials and found that the chrome cobalt (Co-Cr) group was more toxic than the other groups; inflammation increased over time [9]. Magnesium and its alloys have been attracting growing attention as next-generation medical material suitable for biodegradable bone implant and stent, due to their well physical and mechanical properties, such as excellent biocompatibility, high strength, and similar Young's modulus to human bone [10-13]. Magnesium and its alloys' density is approximately $1.8-2.0 \mathrm{~g} \cdot \mathrm{cm}^{-3}$, which is closer to the density of human bone $\left(1.7-2.0 \mathrm{~g} \cdot \mathrm{cm}^{-3}\right)$. Titanium alloy, 316L stainless steel, and cobalt-based alloy were up to $4.0 \mathrm{~g} \cdot \mathrm{cm}^{-3}, 7.9 \mathrm{~g} \cdot \mathrm{cm}^{-3}$ or more, and $8.3 \mathrm{~g} \cdot \mathrm{cm}^{-3}$ or more, respectively. Magnesium alloys' Young's modulus is $41-45 \mathrm{GPa}$, which is closer to that of the human bone density (10-40 GPa), while titanium alloy, 316L stainless steel, and cobalt-based alloy Young's modulus were up to $110 \mathrm{GPa}, 189 \mathrm{GPa}$, and more than $230 \mathrm{GPa}$ [10].

What hindered the development of magnesium alloy was the corrosion resistance of magnesium alloy. As a biocompatible implant material, magnesium alloys were susceptible to corrosion in human body which was rich in $\mathrm{Cl}^{-}$ions, leading to premature failure of its mechanical properties as a key problem for the researchers [14]. In order to improve the corrosion resistance of the biocompatible magnesium alloy, fine-graining [15-17], high-purification [18], alloying [19], and surface treatment $[20,21]$ were commonly used.

Alloying is a hot topic in improving the comprehensive properties of biological magnesium alloys. Ca is an important constituent element of bone tissue, which can increase the 
strength and corrosion resistance of the alloy while increasing the solid solubility of $\mathrm{Zr}$ in the magnesium alloy and promote the refinement of the alloy microstructure $[10,19,22]$. Zr as an alloying element can significantly refine the grains, enhance the tensile strength and yield strength of the alloy, and in the meantime form the precipitation phase to improve the corrosion resistance of the alloy [10, 23]. Sr can promote the growth of osteoblasts, accelerate the healing of bone tissue, and improve the mechanical properties, corrosion resistance, and high temperature creep resistance of the alloy [24-31]. After rolling, the structure can be further refined by HallPetch formula [32]: $\sigma y=\sigma 0+k d-1 / 2$; the fine crystallization can effectively enhance the mechanical properties. The magnesium alloy is packed in hexagons; the fine crystallization strengthening effect is much larger than the face of the cubic aluminum alloy. Ding et al. [28] studied the Zr, Sr in $\mathrm{Mg}-\mathrm{Sr}-\mathrm{Zr}$ alloy of nontoxic side on the human metabolism and the best content on the basis of the achievements of scholars. Sn and Ca were also essential elements of the human body. This study preliminarily analyzed the $\mathrm{Mg}-\mathrm{Ca}$ alloy and added elements which had good biocompatibility. The microstructure, mechanical properties, and corrosion resistance of the magnesium alloy were studied by adding the various amounts of control elements, and the experimental data were provided for the study of corrosion-resistant biocompatible magnesium alloy.

\section{Experimental Method}

2.1. Material Preparation. For comparison, $10 \mathrm{~mm}$ thick plates of pure $\mathrm{Mg}$ (99.99\%) were used for a variety of performance tests.

Four specimens (Alloy 1, Alloy 2, Alloy 3, and Alloy 4) were prepared by using pieces of pure $\mathrm{Mg}$ (99.99\%), Mg30Sr alloy, Mg-10Ca alloy, and pure $\mathrm{Sn}$ and $\mathrm{Mg}-30 \mathrm{Zr}$ alloy (Figure 1). The $10 \mathrm{~mm}$ thick rolling plates of Alloy 1, Alloy 2, Alloy 3, and Alloy 4 were prepared by the following method.

(1) Pieces of the pure $\mathrm{Mg}$, pure $\mathrm{Sn}$, and the alloys were melted in a crucible resistance furnace under the protection of $0.01 \% \mathrm{CO}_{2}+\mathrm{SF}_{6}$. Pieces of $\mathrm{Mg}-30 \mathrm{Sr}$ alloy should be added in the end because they were easy to be burned.

(2) Then $0.1 \% \mathrm{CCl}_{4}$ slag was added in the melts and was heated to $720^{\circ} \mathrm{C}$ for the degassing and grain refining purpose. When the alloy was completely melted and stirred at $720^{\circ} \mathrm{C}$ for 5 minutes, then the temperature was raised to $750^{\circ} \mathrm{C}$ for 20 minutes and the furnace was turned down. After the furnace temperature dropped to $720^{\circ} \mathrm{C}$, the alloy liquid was poured into a steel mold (H13 die steel) which had been preheated to $200^{\circ} \mathrm{C}$ to obtain an ingot. Before pouring, the mold was coated with a thin layer of releasing agent for casting.

(3) After air cooling, the ingot was heated to $300^{\circ} \mathrm{C}$ and placed on a hot rolling mill to be rolled in a mold with dimensions of $\varphi 80 \mathrm{~mm}$ in inner diameter, $20 \mathrm{~mm}$ in wall thickness, and $500 \mathrm{~mm}$ in height and rolled to $10 \mathrm{~mm}$ thickness by one-step molding at a rolling ratio of $16: 1$. Before extrusion, the magnesium alloy bar was kept in a holding furnace at $300^{\circ} \mathrm{C}$ for about 30 minutes to ensure that the bar was completely heated and the extruded cylinder was heated
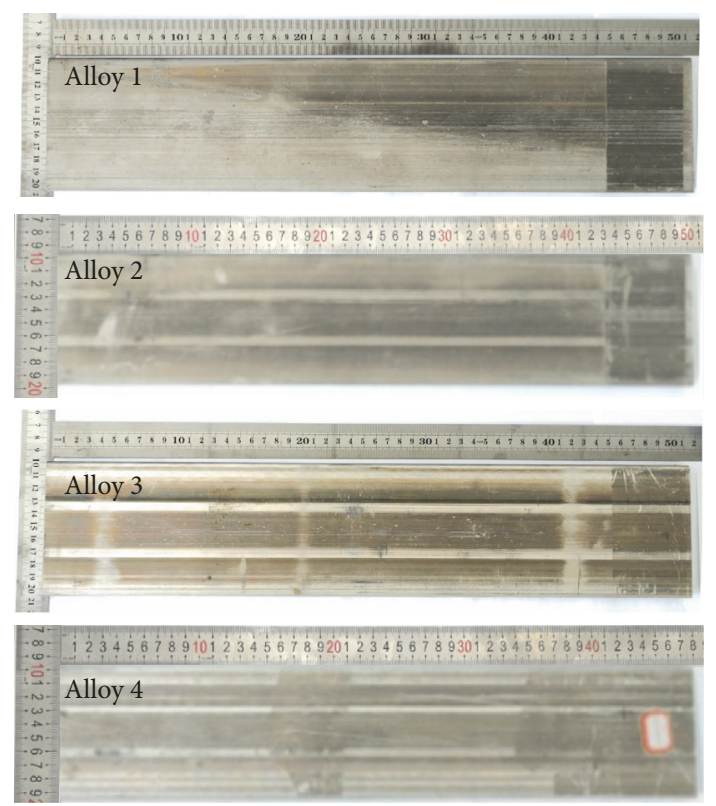

FIgUre 1: Alloy 1, Alloy 2, Alloy 3, and Alloy 4 after rolling.

to $300^{\circ} \mathrm{C}$ before extrusion. Magnesium alloy hot extrusion die coating lubricant was applied.

2.2. Microstructure Characteristics. The alloy samples were cut on the rolled alloy specimens (Table 1) and in parallel direction with rolling. Five samples (pure Mg, Alloy 1, Alloy 2, Alloy 3 , and Alloy 4) were ground from 400 grit to 2000 grit with $\mathrm{SiC}$ sandpaper and polished on a PG-2 metallographic sample polishing machine and then etched with corrosive (distilled water $80 \mathrm{~mL}$, picric acid $5 \mathrm{~g}$, and acetic acid $15 \mathrm{~mL}$ ). The pure $\mathrm{Mg}$ and four as-cast alloys' microstructure was observed by LEICA DM 2500M optical microscope and the EMPYREAN XRD were used to analyze the phase with a $\mathrm{Cu} \mathrm{K} \alpha$ radiation over the range $20^{\circ} \leqslant 2 \theta \leqslant 80^{\circ}$ with an accelerating voltage of $40 \mathrm{kV}$ and a current of $250 \mathrm{mV}$ at room temperature. The samples were scanned at $2 \% \mathrm{~min}$. The morphology of the alloy was observed by MLA 650F SEM, and the composition was analyzed by EDS.

2.3. Mechanical Performance Test. The tensile test samples and compression test samples were cut from rolled $\mathrm{Mg}$ alloy specimens in parallel direction of rolling. For comparison, $3 \mathrm{~mm}$ thick plates of pure $\mathrm{Mg}(99.99 \%)$ were used for a variety of performance tests.

The tensile test specimens (the gauge part was $50 \mathrm{~mm}$ in length, $12.5 \mathrm{~mm}$ in width, and $3 \mathrm{~mm}$ in thickness) and compression test specimens ( $8 \mathrm{~mm}$ high and $5 \mathrm{~mm}$ in diameter) prepared according to ASTM E8 [29], E8M-13a [30], and ASTM E9-89a [31] were stretched and compressed, respectively, using a W-100 microcomputer controlled electronic universal testing machine at a draw rate of $0.5 \mathrm{~mm} / \mathrm{min}$ and a compression test rate of $0.01 \mathrm{~mm} / \mathrm{min}$. Three sets of tensile test specimens and 3 sets of compression test specimens were tested, respectively, and the average values were calculated. 
TABLE 1: The specimens and composition by XRF (mass\%).

\begin{tabular}{|c|c|c|c|}
\hline Rolled alloy specimen & Designed content & Actual content by XRF & $\begin{array}{l}\text { Impurity content by XRF } \\
(\mathrm{wt} \%)\end{array}$ \\
\hline Alloy 1 & $\mathrm{Mg}-0.5 \mathrm{Ca}-1 \mathrm{Sr}-4 \mathrm{Zr}$ & $\mathrm{Mg}-0.45 \mathrm{Ca}-0.74 \mathrm{Sr}-3.99 \mathrm{Zr}$ & $\begin{array}{c}0.016 \% \mathrm{Fe} \\
\mathrm{Si}, \mathrm{Cu}, \mathrm{Ni} \text { undetected. }\end{array}$ \\
\hline Alloy 2 & $\mathrm{Mg}-0.5 \mathrm{Ca}-1 \mathrm{Sr}-1.5 \mathrm{Zr}$ & $\mathrm{Mg}-0.55 \mathrm{Ca}-1.07 \mathrm{Sr}-1.49 \mathrm{Zr}$ & $\begin{array}{l}0.009 \% \mathrm{Fe}, 0.11 \% \mathrm{Si} \\
\mathrm{Cu}, \mathrm{Ni} \text { undetected. }\end{array}$ \\
\hline Alloy 3 & $\mathrm{Mg}-0.5 \mathrm{Ca}-3.5 \mathrm{Sr}-1.5 \mathrm{Zr}$ & $\mathrm{Mg}-0.54 \mathrm{Ca}-3.37 \mathrm{Sr}-1.37 \mathrm{Zr}$ & $\begin{array}{c}0.017 \% \mathrm{Fe}, 0.083 \% \mathrm{Si} \\
\mathrm{Cu}, \mathrm{Ni} \text { undetected. }\end{array}$ \\
\hline Alloy 4 & $\mathrm{Mg}-0.5 \mathrm{Ca}-1 \mathrm{Sr}-0.5 \mathrm{Sn}$ & $\mathrm{Mg}-0.43 \mathrm{Ca}-1.21 \mathrm{Sr}-0.48 \mathrm{Sn}$ & $\begin{array}{l}0.020 \% \mathrm{Fe}, 0.12 \% \mathrm{Si} \\
\mathrm{Cu}, \mathrm{Ni} \text { undetected. }\end{array}$ \\
\hline
\end{tabular}

2.4. Electrochemical Tests. Alloy samples cut into $1 \mathrm{~cm} *$ $1 \mathrm{~cm} * 1 \mathrm{~cm}$ pieces were ground from 400 grit to 2000 grit with $\mathrm{SiC}$ sandpaper and polished on a PG-2 metallographic sample polishing machine and then placed in Hank's physiological solution at a constant temperature of $37^{\circ} \mathrm{C}$ (Hank's solution composition: $8.01 \mathrm{~g} / \mathrm{L} \mathrm{NaCl}, 0.40 \mathrm{~g} / \mathrm{L} \mathrm{KCl}$, $0.19 \mathrm{~g} / \mathrm{L} \mathrm{CaCl}, 0.051 \mathrm{~g} / \mathrm{L} \mathrm{Na}_{2} \mathrm{HPO}_{4} \cdot \mathrm{H}_{2} \mathrm{O}, 0.055 \mathrm{~g} / \mathrm{L} \mathrm{KH}_{2} \mathrm{PO}_{4}$, $0.353 \mathrm{~g} / \mathrm{L} \mathrm{NaHCO}_{3}$, and $0.346 \mathrm{~g} / \mathrm{L} \mathrm{MgSO}_{4} \cdot 7 \mathrm{H}_{2} \mathrm{O}$ ) to evaluate the corrosion rate with hydrogen evolution. The epoxy resin protection was made on specimens and the specimens were only $0.5 \mathrm{~cm}^{2}$ exposed to the solution. The CS310 multifunction electrochemical workstation was applied with calomel electrode as the reference electrode; Pt was applied as the auxiliary electrode of the three-electrode system to measure the open circuit potential. The scanning speed was set at $1 \mathrm{mv} / \mathrm{s}$ to measure the polarization curve. The dynamic potential scanning range of $-0.5 \mathrm{~V}$ to $1.5 \mathrm{~V}$ and Tafel traditional method were used for fitting.

2.5. Cell Culture. Cells for CVR test were cultured in low-limit basal medium (MEM) (Gibco, Invitrogen, Mulgrave, VIC, Australia) (Barwon Biomedical Research, Geelong Hospital, Victoria, Australia) with osteoblast characteristics. Other reagents include $10 \%$ fetal bovine serum (Bovogen (SigmaAldrich, Castle Hill, NSW, Australia), 10,000 units/mL penicillin-10000 $\mu \mathrm{g} / \mathrm{mL}$ streptomycin (Gibco) and $0.4 \%$ amphostat B (In Vitro Technologies), 1\% nonessential amino acids (Sigma-Aldrich, Castle Hill, NSW, Australia), Auckland, New Zealand) and were cultured in a humidified air atmosphere at $37^{\circ} \mathrm{C}$ and $5 \% \mathrm{CO}_{2}$. The medium was replaced every 3 days.

2.6. Cell Viability Ratio (CVR) Test. The Mg-Ca alloy samples of $\varphi 8 \times 2 \mathrm{~mm}$ were sterilized at $180^{\circ} \mathrm{C}$ for $2 \mathrm{~h}$ and then placed into the cell culture plate with control samples, $5 \times 103$ cells were seeded on each sample for 7 days, and the biocompatibility was evaluated by the international standard ISO10993-5 [33].

\section{Results and Discussion}

3.1. Composition and Microstructure. Rolled alloy specimens are listed in Table 1 . Three small samples $(1 \mathrm{~cm} * 1 \mathrm{~cm} * 10$ $\mathrm{cm})$ were cut at three different locations on the specimens. Elemental compositions of three samples were tested by S4

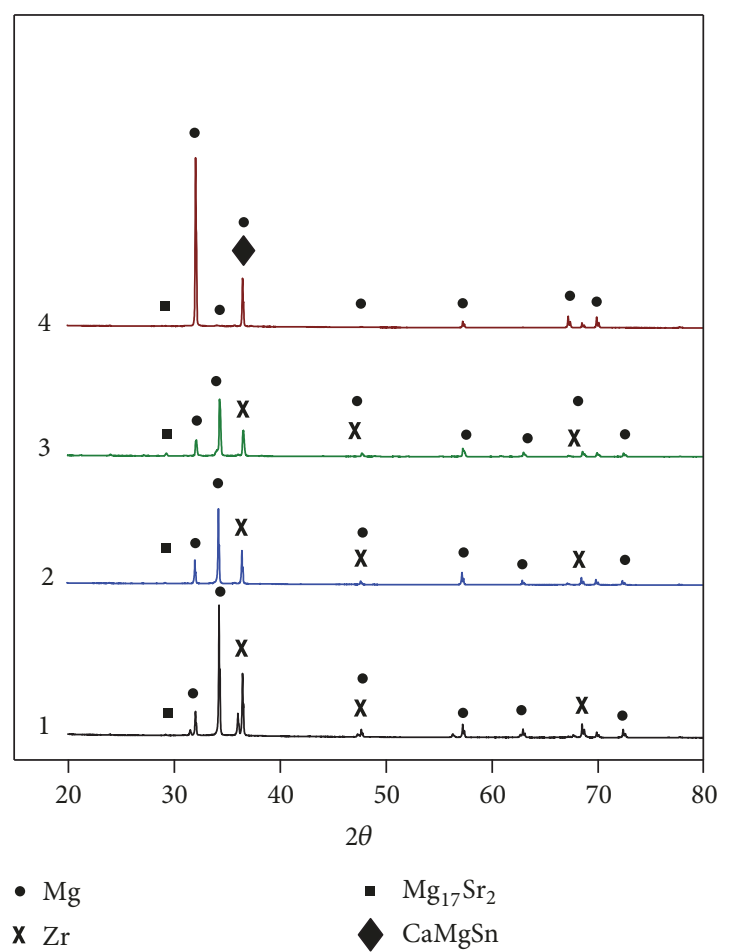

FIGURE 2: XRD patterns of rolled Alloy 1, Alloy 2, Alloy 3, and Alloy 4.

PIONEER XRF and the results listed in Table 1 were the average content.

Chemical analysis of Alloy 1 showed that average content of $\mathrm{Zr}$ was 3.97, and 3 samples were 3.88, 4.10, and 3.95, respectively. Average content of $\mathrm{Zr}$ in Alloy 2 was 1.48 , and 3 samples were $1.48,1.39$, and 1.58 , respectively. Average content of $\mathrm{Zr}$ in Alloy 3 was 1.37, and 3 samples were 1.29, 1.36, and 1.47 , respectively. Hence, there was macrosegregation of the elements in Alloy 1, Alloy 2, and Alloy 3.

Chemical analysis showed that there was no macrosegregation of the elements in Alloy 4. Average content of Sn in Alloy 4 was 0.48 , and 3 samples were $0.47,0.48$, and 0.48 , respectively.

Phase compositions of four magnesium alloys were determined by XRD (Figure 2). It could be seen from the figure that Alloy 1, Alloy 2, and Alloy 3 were mainly composed of $\alpha$ $\mathrm{Mg}$ matrix, $\mathrm{Zr}$, and intermetallic compound $\mathrm{Mg}_{17} \mathrm{Sr}_{2}$. After 


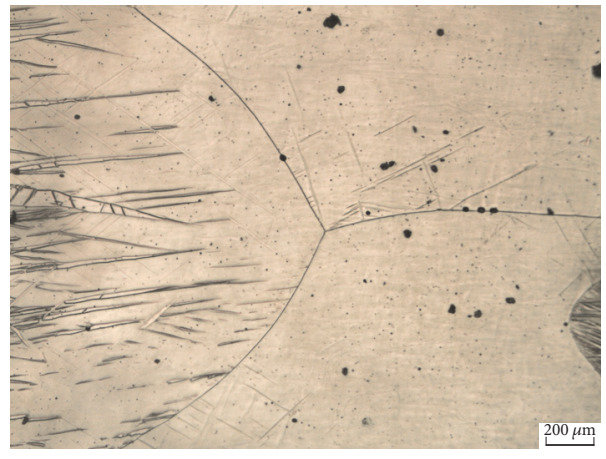

(a)

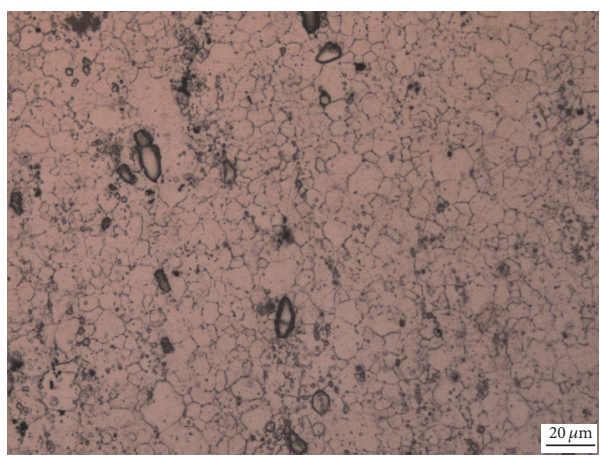

(c)

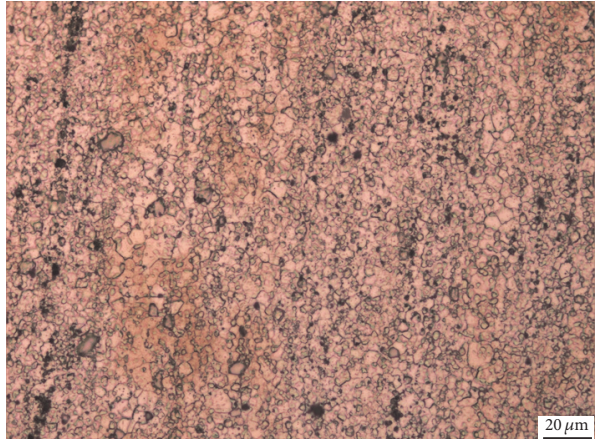

(b)

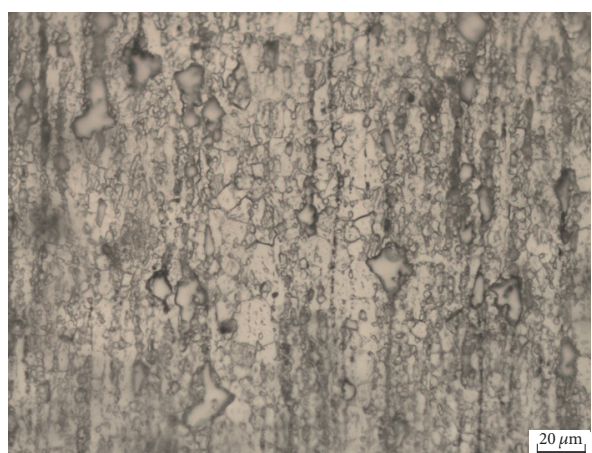

(d)

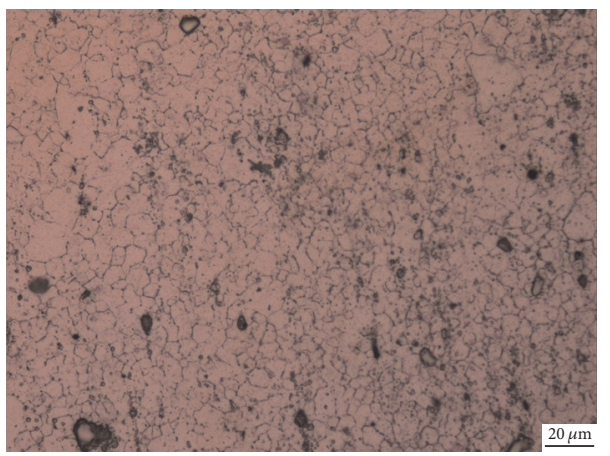

(e)

Figure 3: Microstructures of the cross sections of rolled alloys: (a) pure Mg; (b) Alloy 1; (c) Alloy 2; (d) Alloy 3; (e) Alloy 4.

adding $\mathrm{Sn}, \mathrm{CaMgSn}$ phase was formed beside $\alpha-\mathrm{Mg}$ matrix and $\mathrm{Mg}_{17} \mathrm{Sr}_{2}$, and the diffraction angle of the strongest peak showed deviation, which may be due to the rolling of as-cast alloy and different additives.

Figure 3 shows the cross-section metallographic photographs of pure $\mathrm{Mg}$ and four groups of rolled magnesium alloy (Alloy 1, Alloy 2, Alloy 3, and Alloy 4). It can be seen from the figure that, compared to pure $\mathrm{Mg}$ in Figure 3(a), the grain sizes of magnesium alloy had been refined after rolling, which might be caused by alloying and alloy dynamic recrystallization. The black points should be pure $\alpha-\mathrm{Zr}$ particles (the maximum solid solubility in the magnesium alloy is $0.6 \%$ ), and the XRD spectrum of Figure 2 shows that Alloy 1 had a strong $\mathrm{Zr}$ prime peak. Although the average grain sizes of Figure 3(e) were $9.7 \mu \mathrm{m}$ according to linear intercept method in ASTM E112 [34], which was significantly larger than that of Figure 3(b), $5.36 \mu \mathrm{m}$, Figure 3(c), $6.71 \mu \mathrm{m}$, and Figure 3(d), $6.16 \mu \mathrm{m}$, it can be seen that the distribution of the components in Figure 3(e) was relatively uniform. After being rolled, the grains in the alloys were found to be stretched and there were some incomplete recrystallization and recovery zones. In addition, the cross sections were formed by equiaxed grains. The dynamic recrystallization after rolling was secondarily refined to that of the grains.

Figure 4 shows SEM, Zr EDS, and Sn EDS images of Alloy 1, Alloy 2, Alloy 3, and Alloy 4, respectively. In Figures 4(a2), 4(b2), and 4(c2), it can be seen that the irregular circular white areas were $\alpha$-Zr-rich segregation areas, and the distribution of $\mathrm{Zr}$ was not very uniform. The crystallization of Alloy 1 , Alloy 2 , and Alloy 3 was more refined than that of pure magnesium (Figure 3 ) because a small amount of $\mathrm{Zr}$ was cosolid-solved into the $\alpha$-Mg matrix.

The uniformly distributed Sn element was found by EDS mapping in Figure 4(d2). Therefore, the crystallization of 


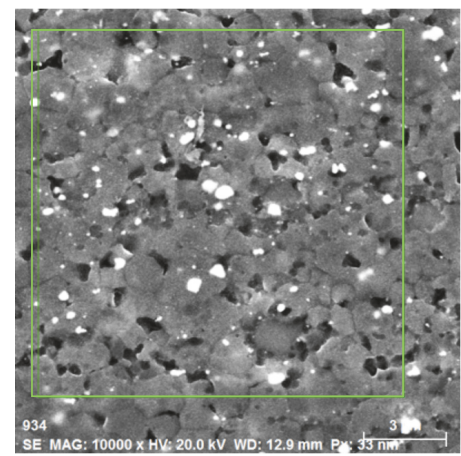

(a1)

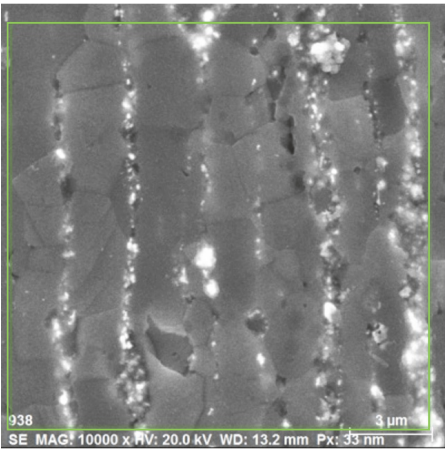

(b1)

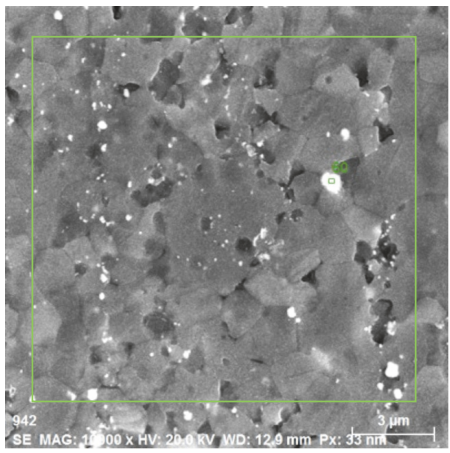

(c1)

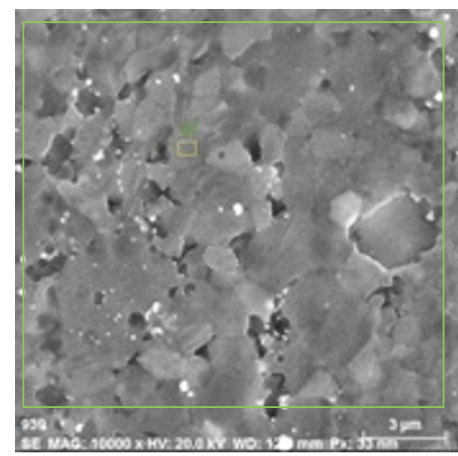

(d1)

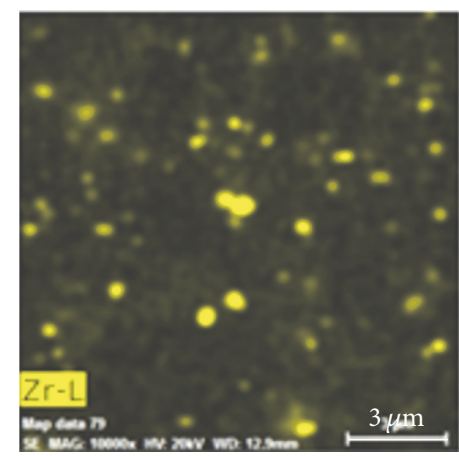

(a2)

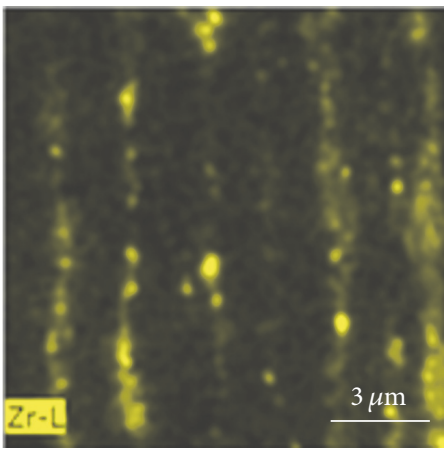

(b2)

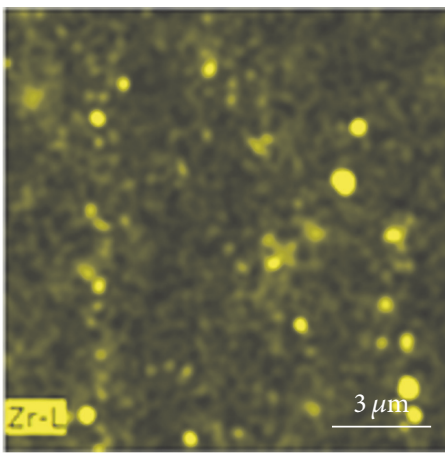

(c2)

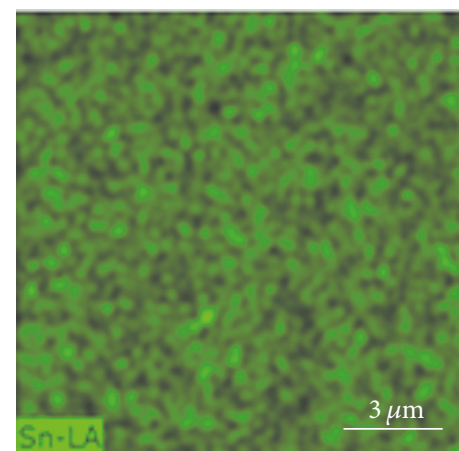

(d2)

FIGURE 4: Images of (a1) SEM of Alloy 1, (a2) Zr EDS pattern of Alloy 1, (b1) SEM of Alloy 2, (b2) Zr EDS pattern of Alloy 2, (c1) SEM of Alloy 3, (c2) Zr EDS pattern of Alloy 3, (d1) SEM of Alloy 4, and (d2) Sn EDS pattern of Alloy 4. 


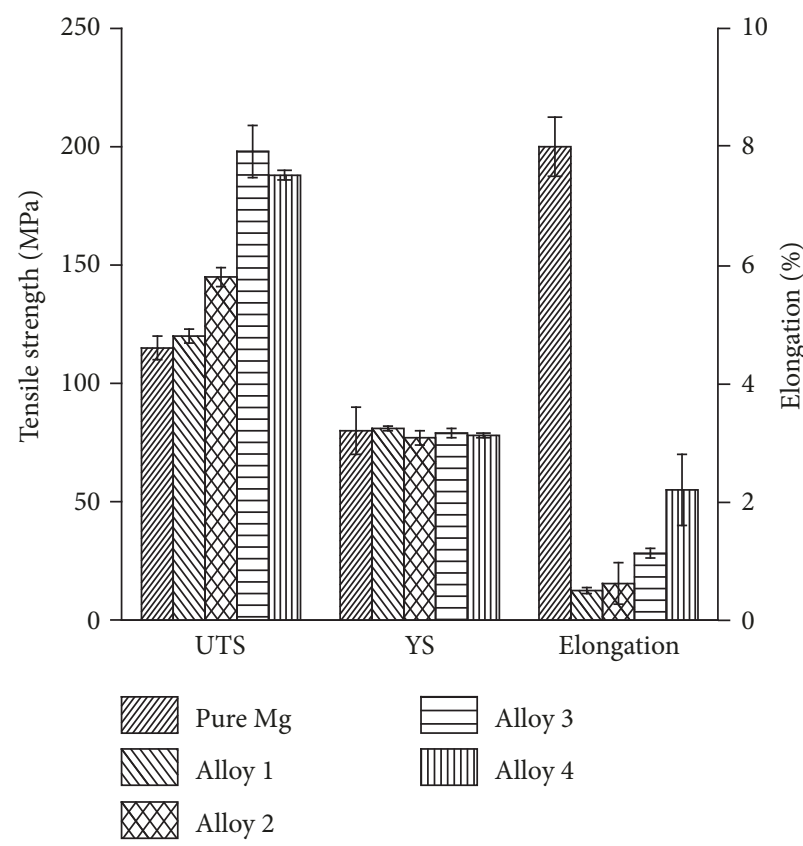

(a)

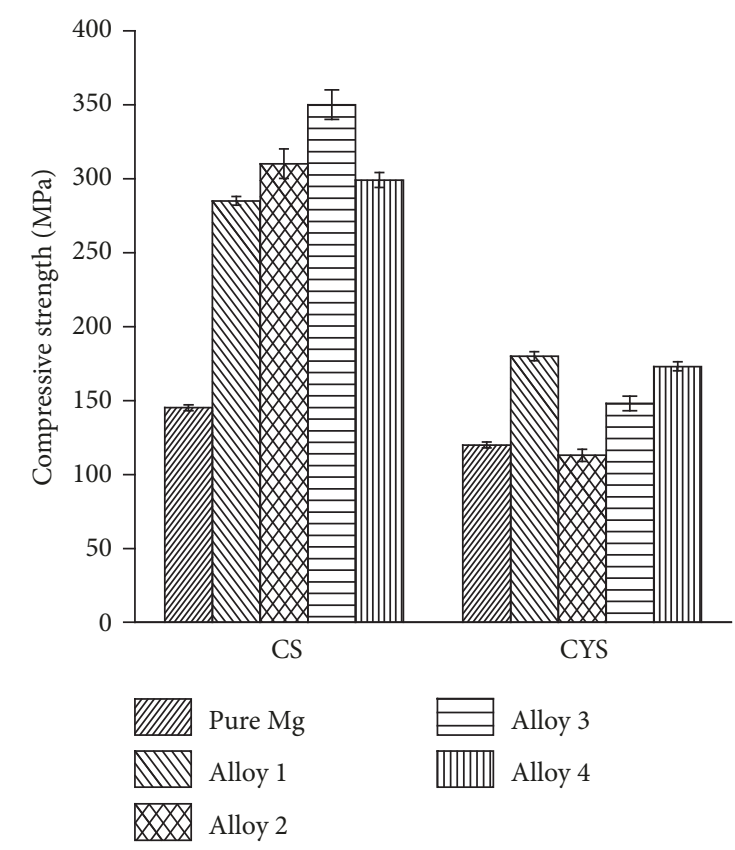

(b)

FIGURE 5: Tensile strength and elongation (a) and compressive strength (b) of pure Mg and Alloy 1, Alloy 2, Alloy 3, and Alloy 4.

Alloy 4 was more refined than that of pure magnesium and Alloy 1, Alloy 2, and Alloy 3 (Figure 3).

3.2. Mechanical Properties. The mechanical properties of pure $\mathrm{Mg}$ and four alloys are shown in Figure 5. The comprehensive mechanical properties of four rolling alloys were much higher than those of pure $\mathrm{Mg}$, which may be due to factors such as solid solution and second-phase strengthening of $\mathrm{Zr}$, Ca and work hardening of $\mathrm{Mg}_{2} \mathrm{Sn}, \mathrm{Mg}_{17} \mathrm{Sr}_{2}$. The compressive strength of Alloy 3 was relatively better than others. $\mathrm{Mg}_{17} \mathrm{Sr}_{2}$ phases in alloys could refine crystalline grains. The elongation of Alloy 4 was higher than that of 3 alloys, demonstrating that the $\mathrm{Mg}_{17} \mathrm{Sr}_{2}$ phases in the alloy homogenized the distribution of CaMgZn phases and contributed to the alloy elongation.

Compressive strength of the alloys was more than twice as high as that of pure magnesium. This was because a large number of second-phase particles $\left(\mathrm{Mg}_{2} \mathrm{Sn}, \mathrm{Mg}_{17} \mathrm{Sr}_{2}\right)$ greatly improve the compressive strength of the alloys.

3.3. Corrosion Resistance. As shown in Figure 6, pure $\mathrm{Mg}$ and Mg alloys 1, 2, 3, and 4 were immersed in Hank's solution at $37^{\circ} \mathrm{C}$ to evaluate the amount of hydrogen evolution with immersion time. It can be seen from the figure that the curve of Alloy 4 was close to a straight line in the 120 -hour experimental period, indicating that Alloy 4 basically remained in a relatively consistent dissolution rate. The other four groups of alloys and pure $\mathrm{Mg}$ were initially in rapid hydrogen evolution rate; then the rate began to decline as time went on. It can be seen from the figure that only the hydrogen deposition amount of Alloy 4 was close to that of pure $\mathrm{Mg}$ and was more resistant to corrosion than pure Mg. Corrosion resistance of

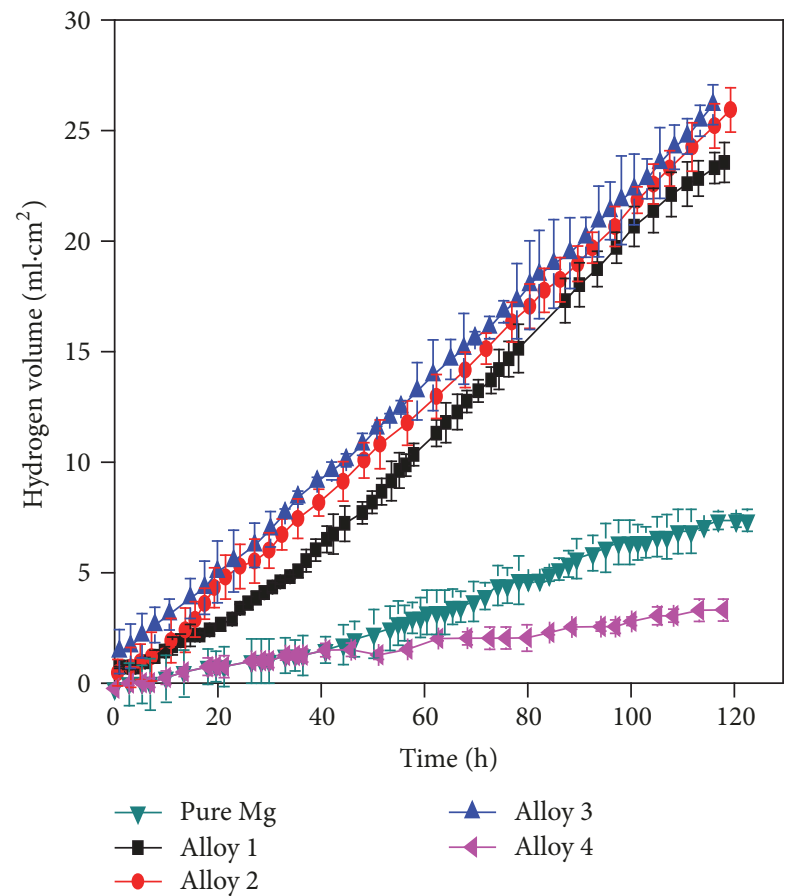

FIGURE 6: Variations of hydrogen evolution volumes of pure $\mathrm{Mg}$ and $\mathrm{Mg}$ alloys in Hank's solution with immersion time.

Alloy 1, Alloy 2, and Alloy 3 was relatively closer, which was inferior to that of pure Mg. According to the daily precipitation of hydrogen, from the formula $\mathrm{ph}=2.279 \mathrm{Vh}$ [35], the calculation result of the corrosion rate of the alloys per year is shown in Table 2. 


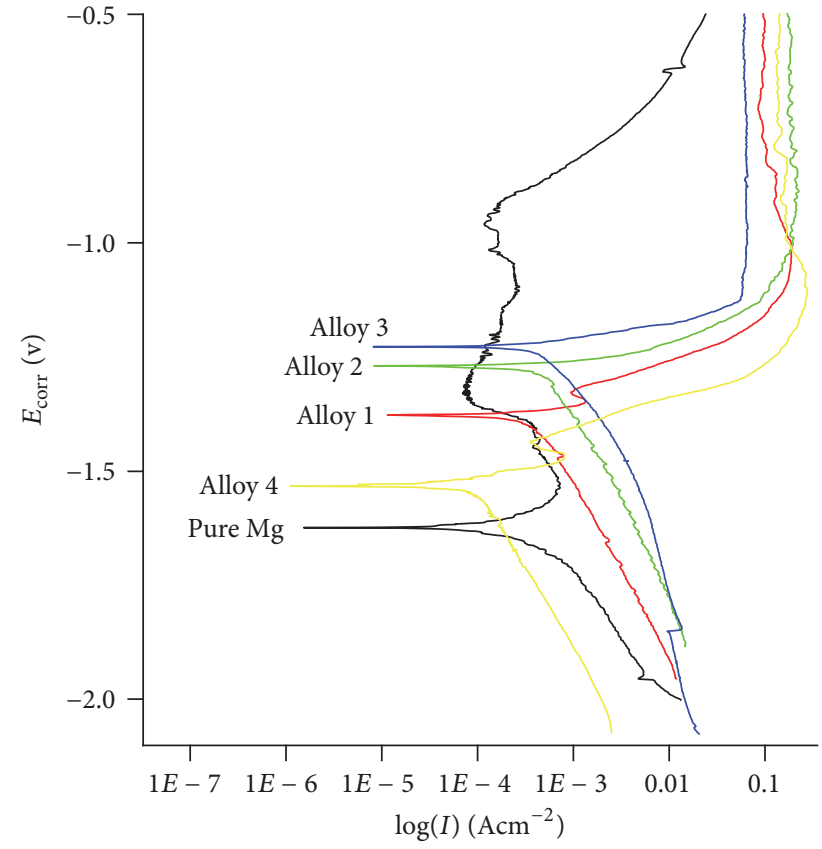

Figure 7: Polarization curves in Hank's solution of rolled pure Mg and $\mathrm{Mg}$ alloys.

Figure 7 is the polarization curve of pure $\mathrm{Mg}$ and $\mathrm{Mg}$ Alloy 1, Alloy 2, Alloy 3, and Alloy 4 in Hank's solution at $37^{\circ} \mathrm{C}$. It can be seen from the figure that, in the cathode region, the corrosion current of Alloy 4 was much smaller than that of pure $\mathrm{Mg}$ and other 3 alloys at the same potential, and the corrosion current of the other 3 alloys was larger than that of pure $\mathrm{Mg}$, indicating that the corrosion resistance of Alloy 4 was most optimal, and other alloys were less corrosionresistive than pure $\mathrm{Mg}$, which was accordant with the results measured by the hydrogen evolution method. In the anode area, it was apparent that pure $\mathrm{Mg}$ and Alloy 4 had inflection points, respectively, indicating that corrosion-resistant passivation films were formed, thereby reducing the corrosion rate, while inflection points in the other three groups of alloys were not particularly significant and are basically close to active dissolution, especially Alloy 3 . The results were fitted by Tafel traditional method, and the corrosion potential and current density are shown in Table 4.

Table 3 shows the corrosion potential $\left(E_{\text {corr }}\right)$ and corrosion current densities $\left(I_{\text {corr }}\right)$ of phosphate coatings. Electrochemical parameters showed results correspond to potentiodynamic polarization curves of the alloys shown in Figure 7. $E_{\text {corr }}$ of Alloy 1, Alloy 2, Alloy 3, and Alloy 4 showed lower $E_{\text {corr }}$ than that of pure $\mathrm{Mg}$. The Mg-0.5Ca- $1 \mathrm{Sr}-0.5 \mathrm{Sn}$ alloy demonstrated lowest corrosion current and corrosion rate in electrochemical test; $I_{\text {corr }}$ was $25 \%$ of that of pure magnesium and showed delayed corrosion in Hank's solution.

Figure 8 shows SEM images of Alloy 1, Alloy 2, Alloy 3 , and Alloy 4 after being immersed in Hank's solution for $120 \mathrm{~h}$ and washing away the corrosion product. Corrosion microcracks could be seen and they were not shown in the original morphologies on the surface of Alloy 1 and Alloy 2 samples. There were severe bulges because $\alpha-\mathrm{Zr}$ in the
TABLE 2: Hydrogen evolution and corrosion rates of pure Mg and $\mathrm{Mg}$ alloys in Hank's solution.

\begin{tabular}{lcc}
\hline Samples & $\begin{array}{c}\mathrm{H}_{2} \text { evolution rate } \\
\mathrm{mL} /\left(\mathrm{cm}^{2} \text { day }\right)\end{array}$ & $\begin{array}{c}\text { Corrosion rate } \\
\mathrm{mm} / \text { year }\end{array}$ \\
\hline Pure $\mathrm{Mg}$ & 1.43 & 3.26 \\
Alloy 1 & 4.79 & 10.92 \\
Alloy 2 & 5.14 & 11.71 \\
Alloy 3 & 5.32 & 12.11 \\
Alloy 4 & 0.68 & 1.56 \\
\hline${ }^{(1)}$ Corrosion rate $\mathrm{mm} /$ year was calculated with $\mathrm{H}_{2}$ production rate.
\end{tabular}

Zr-rich region acted as cathode in corrosion galvanic and accelerated the corrosion in the process of corrosion. That is the reason why the corrosion resistance of Alloy 1 and Alloy 2 was poor. The original morphology on the surface of Alloy 3 samples was more complete but there were bulges because of electrochemistry corrosion.

The original morphology on the surface of Alloy 3 samples was more complete without corrosion. $\mathrm{Mg}_{17} \mathrm{Sn}_{2}$ compounds made CaMgSn homogeneous and corrosion was blocked.

3.4. Biocompatibility Assessment. Table 4 shows the cell viability ratio (CVR) values used for assessing the in vitro cytotoxicities of the $\mathrm{Mg}$-Ca alloys, compared to control group. The cell viability ratio (CVR) was calculated using the equation given by [36]:

$$
\text { CVR }=\frac{\text { (viable cell count in experimental extract) }}{\text { (viable cell count in control extract) }} .
$$

As can be seen from Figure 9, the cell viability ratio (CVR) values of Alloy 1, Alloy 2, Alloy 3, and Alloy 4 were $0.89,0.94$, 0.87 , and 0.92 , respectively. They were close to the results of the control group, where Alloy 2 and Alloy 4 showed slightly higher CVR in the materials evaluated. Therefore, it can be inferred that Alloy 2 and Alloy 4 had better cell compatibility.

\section{Conclusion}

A new series of $\mathrm{Mg}$-Ca alloys including $\mathrm{Mg}-0.5 \mathrm{Ca}-1 \mathrm{Sr}-4 \mathrm{Zr}$, $\mathrm{Mg}-0.5 \mathrm{Ca}-1 \mathrm{Sr}-1.5 \mathrm{Zr}, \mathrm{Mg}-0.5 \mathrm{Ca}-3 \mathrm{Sr}-1.5 \mathrm{Zr}$, and $\mathrm{Mg}-0.5 \mathrm{Ca}-1 \mathrm{Sr}-$ $0.5 \mathrm{Sn}$ were designed using the vacuum smelting, gravity casting, and hot rolling approaches. The microstructures, mechanical properties, and cytocompatibility of the $\mathrm{Mg}-\mathrm{Ca}$ alloys were investigated. The following conclusions can be drawn from this study.

(1) The alloys were composed of $\alpha-\mathrm{Mg}, \alpha-\mathrm{Zr}, \mathrm{Mg}_{12} \mathrm{Sr}_{7}$, and $\mathrm{CaMgSn}$, and their grain sizes were dramatically refined compared with that of pure $\mathrm{Mg}$, which were characterized by optical microscopy, XRD, and EDS.

(2) The comprehensive mechanical properties of alloys containing $\mathrm{Zr}$ were greatly improved; $\mathrm{Mg}-0.5 \mathrm{Ca}-3 \mathrm{Sr}-1.5 \mathrm{Zr}$ alloy obtained the highest tensile strength of approximately $200 \mathrm{MPa}$ and highest compression strength at $350 \mathrm{MPa}$. But the corrosion resistance of $\mathrm{Mg}$-Ca-Sr-Zr alloys was not 
TABLE 3: Electrochemical parameters of pure Mg and Mg alloys.

\begin{tabular}{lccc}
\hline Sample code & $E_{\text {corr }}(\mathrm{V})$ & $I_{\text {corr }}\left(\mathrm{mA} / \mathrm{cm}^{2}\right)$ & Corrosion rate $(\mathrm{mm} /$ year $)$ \\
\hline Pure Mg & -1.38 & 0.48 & 10.39 \\
Alloy 1 & -1.26 & 0.72 & 15.63 \\
Alloy 2 & -1.21 & 0.74 & 16.12 \\
Alloy 3 & -1.48 & 3.09 & 67.06 \\
Alloy 4 & -1.55 & 0.11 & 2.42 \\
\hline
\end{tabular}

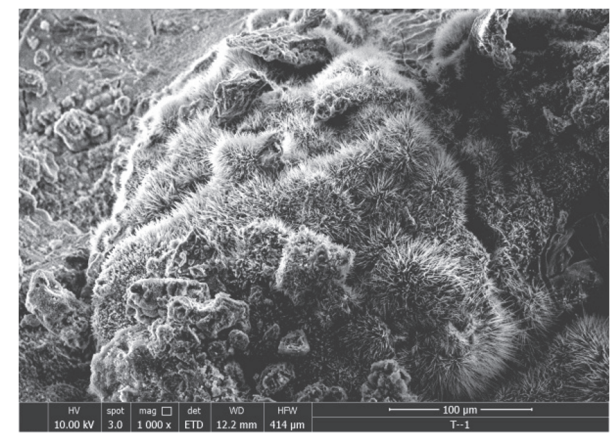

(a)

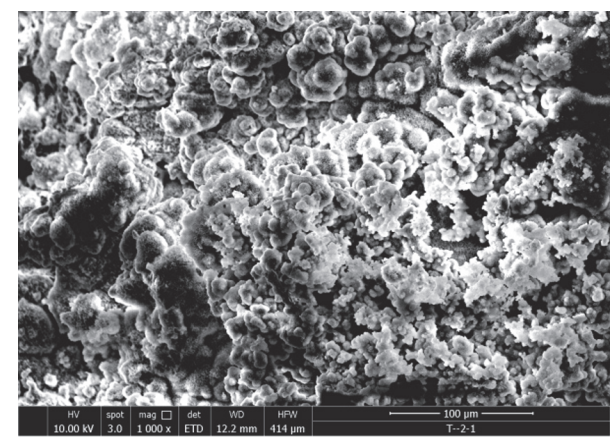

(c)

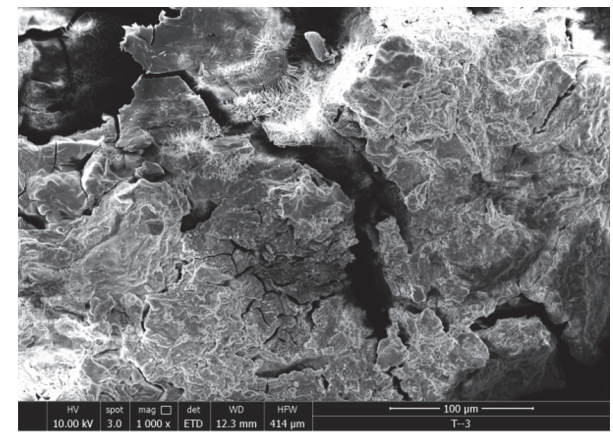

(b)

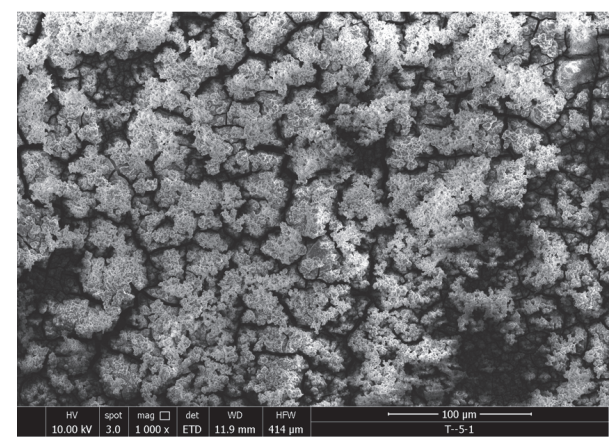

(d)

FIgUre 8: The SEM images of the alloys immersed in Hank's solution after 120 h: (a) Alloy 1; (b) Alloy 2; (c) Alloy 3; (d) Alloy 4.

TABLE 4: Cell viability ratio of alloys after $24 \mathrm{~h}$ extract cell seed for 1 day and then cell cultures for 5 days.

\begin{tabular}{lccccc}
\hline & \multicolumn{3}{c}{ Viability (\% of control) } & Average (\%) & STD \\
& 1 & 2 & 3 & & \\
\hline Control & 99.99 & 98.54912 & 101.4509 & $100 \%$ & 1.18 \\
Alloy 1 & 80.05 & 91.2 & 94.45 & 88.57 & 7.55 \\
Alloy 2 & 94.7 & 92.41 & 96.1 & 94.40 & 1.86 \\
Alloy 3 & 91.7154 & 87.32 & 82.6 & 87.21 & 4.56 \\
Alloy 4 & 84.4 & 96.2 & 94.89 & 91.83 & 6.47 \\
\hline
\end{tabular}

as good as that of pure Mg. The alloy showed balanced mechanical properties, with tensile strength of $180 \mathrm{Mpa}$ and compressive strength of $340 \mathrm{Mpa}$, which was a bit lower than $\mathrm{Mg}-0.5 \mathrm{Ca}-3 \mathrm{Sr}-1.5 \mathrm{Zr}$ alloy, but superior to pure $\mathrm{Mg}$.

(3) The Mg-0.5Ca-1Sr-0.5Sn alloy released the least hydrogen in Hank's solution, which was lower than that of pure magnesium. Electrochemical test results in Hank's solution further showed that the Mg-0.5Ca-1Sr-0.5Sn alloy had delayed corrosion and lowest $I_{\text {corr }}$ which was $25 \%$ of that of pure magnesium.

(4) The Mg-Ca alloys exhibited excellent cytocompatibility on osteoblast-like cells $\left(\mathrm{SaOS}_{2}\right)$.

\section{Conflicts of Interest}

The authors declare that there are no conflicts of interest regarding the publication of this paper. 


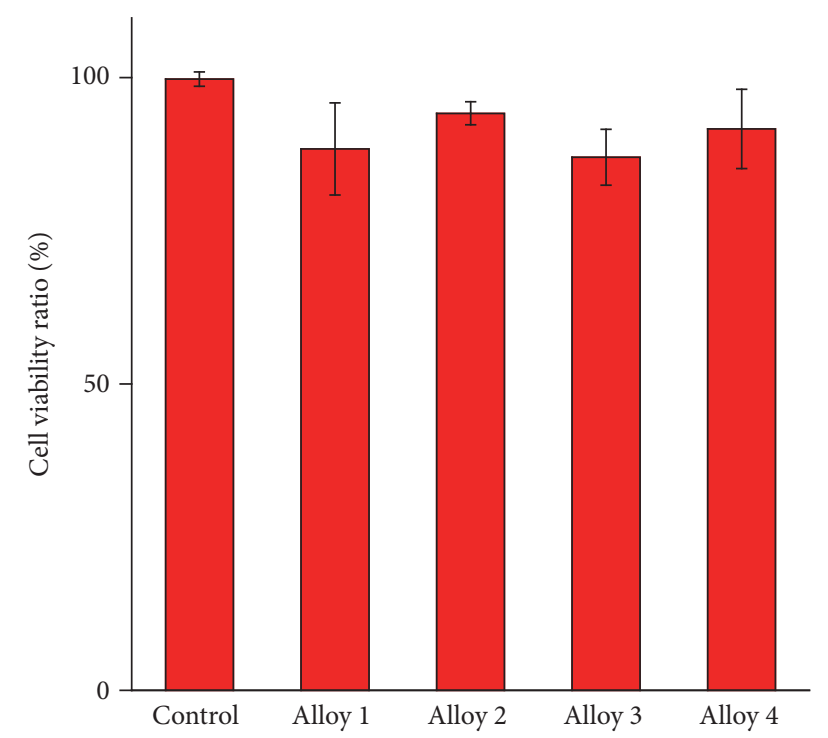

Figure 9: Cell viability ratio of alloys after $24 \mathrm{~h}$ extract cell seed for 1 day and then cell cultures for 5 days.

\section{References}

[1] R. Agarwal and A. J. García, "Biomaterial strategies for engineering implants for enhanced osseointegration and bone repair," Advanced Drug Delivery Reviews, vol. 94, pp. 53-62, 2015.

[2] D. Gopi, S. Ramya, D. Rajeswari, and L. Kavitha, "Corrosion protection performance of porous strontium hydroxyapatite coating on polypyrrole coated 316L stainless steel," Colloids and Surfaces B: Biointerfaces, vol. 107, pp. 130-136, 2013.

[3] K. A. O. Arafa, "Comparing the effects of titanium alloy and chrome cobalt in removable partial denture connectors on tooth mobility, bone loss and tissue reaction," Saudi Journal for Dental Research, vol. 7, no. 2, pp. 112-117, 2016.

[4] H. M. Ayu, S. Izman, R. Daud et al., "Surface modification on CoCrMo alloy to improve the adhesion strength of hydroxyapatite coating," Procedia Engineering, vol. 184, pp. 399-408, 2017.

[5] M. Long and H. J. Rack, "Titanium alloys in total joint replacement-a materials science perspective," Biomaterials, vol. 19, no. 18, pp. 1621-1639, 1998.

[6] M. Niinomi, "Recent research and development in titanium alloys for biomedical applications and healthcare goods," Science and Technology of Advanced Materials, vol. 4, no. 5, pp. 445-454, 2003.

[7] H. J. Rack and J. I. Qazi, "Titanium alloys for biomedical applications," Materials Science and Engineering C: Materials for Biological Applications, vol. 26, no. 8, pp. 1269-1277, 2006.

[8] P. Haudrechy, J. Foussereau, B. Mantout, and B. Baroux, "Nickel release from 304 and 316 stainless steels in synthetic sweat. Comparison with nickel and nickel-plated metals. Consequences on allergic contact dermatitis," Corrosion Science, vol. 35, no. 1-4, pp. 329-336, 1993.

[9] B. Ebadian, M. Razavi, S. Soleimanpour, and R. Mosharraf, "Evaluation of tissue reaction to some denture- base materials: An animal study," Journal of Contemporary Dental Practice, vol. 4, no. 9, pp. 64-67, 2008.
[10] M. P. Staiger, A. M. Pietak, J. Huadmai, and G. Dias, "Magnesium and its alloys as orthopedic biomaterials: a review," Biomaterials, vol. 27, no. 9, pp. 1728-1734, 2006.

[11] Z. Li, X. Gu, S. Lou, and Y. Zheng, "The development of binary $\mathrm{Mg}$-Ca alloys for use as biodegradable materials within bone," Biomaterials, vol. 29, no. 10, pp. 1329-1344, 2008.

[12] S.-H. Chang, L. Niu, Y. Su, W. Wang, X. Tong, and G. Li, "Effect of the pretreatment of silicone penetrant on the performance of the chromium-free chemfilm coated on AZ91D magnesium alloys," Materials Chemistry and Physics, 2016.

[13] X.-B. Chen, N. Birbilis, and T. B. Abbott, "Effect of $\left[\mathrm{Ca}^{2+}\right]$ and $\left[\mathrm{PO}_{4}^{3-}\right]$ levels on the formation of calcium phosphate conversion coatings on die-cast magnesium alloy AZ91D," Corrosion Science, vol. 55, pp. 226-232, 2012.

[14] C. Castellani, R. A. Lindtner, P. Hausbrandt et al., "Boneimplant interface strength and osseointegration: biodegradable magnesium alloy versus standard titanium control," Acta Biomaterialia, vol. 7, no. 1, pp. 432-440, 2011.

[15] W. Zhang, M. Li, Q. Chen et al., "Effects of Sr and Sn on microstructure and corrosion resistance of $\mathrm{Mg}-\mathrm{Zr}-\mathrm{Ca}$ magnesium alloy for biomedical applications," Materials \& Design, vol. 39, pp. 379-383, 2012.

[16] S. Chen, S. Guan, B. Chen et al., "Corrosion behavior of $\mathrm{TiO}_{2}$ films on Mg-Zn alloy in simulated body fluid," Applied Surface Science, vol. 257, no. 9, pp. 4464-4467, 2011.

[17] T. Kraus, S. F. Fischerauer, A. C. Hänzi, P. J. Uggowitzer, J. F. Löffler, and A. M. Weinberg, "Magnesium alloys for temporary implants in osteosynthesis: in vivo studies of their degradation and interaction with bone," Acta Biomaterialia, vol. 8, no. 3, pp. 1230-1238, 2012.

[18] X. Gu, Y. Zheng, Y. Cheng, S. Zhong, and T. Xi, "In vitro corrosion and biocompatibility of binary magnesium alloys," Biomaterials, vol. 30, no. 4, pp. 484-498, 2009.

[19] W.-C. Kim, J.-G. Kim, J.-Y. Lee, and H.-K. Seok, "Influence of $\mathrm{Ca}$ on the corrosion properties of magnesium for biomaterials," Materials Letters, vol. 62, no. 25, pp. 4146-4148, 2008.

[20] M. Bornapour, N. Muja, D. Shum-Tim, M. Cerruti, and M. Pekguleryuz, "Biocompatibility and biodegradability of $\mathrm{Mg}-\mathrm{Sr}$ alloys: The formation of Sr-substituted hydroxyapatite," Acta Biomaterialia, vol. 9, no. 2, pp. 5319-5330, 2013.

[21] X. N. Gu, X. H. Xie, N. Li, Y. F. Zheng, and L. Qin, "In vitro and in vivo studies on a $\mathrm{Mg}$-Sr binary alloy system developed as a new kind of biodegradable metal," Acta Biomaterialia, vol. 8, no. 6, pp. 2360-2374, 2012.

[22] B. H. Kim, J. J. Jeon, K. C. Park, B. G. Park, Y. H. Park, and I. M. Park, "Microstructural characterisation and mechanical properties of Mg-xSn-5Al-1Zn alloys," International Journal of Cast Metals Research, vol. 21, no. 1-4, pp. 186-192, 2008.

[23] B. H. Kim, K. C. Park, Y. H. Park, and I. M. Park, "Effect of $\mathrm{Ca}$ and $\mathrm{Sr}$ additions on high temperature and corrosion properties of Mg-4Al-2Sn based alloys," Materials Science and Engineering: A Structural Materials: Properties, Microstructure and Processing, vol. 528, no. 3, pp. 808-814, 2011.

[24] K. C. Park, B. H. Kim, J. J. Jeon, B. G. Park, Y. H. Park, and I. M. Park, "Influence of $\mathrm{Sr}$ and $\mathrm{Zn}$ additions on corrosion behaviour of Mg-6Sn-5Al-2Si alloys," International Journal of Cast Metals Research, vol. 21, no. 1-4, pp. 96-99, 2008.

[25] A. Kozlov, M. Ohno, R. Arroyave, Z. K. Liu, and R. SchmidFetzer, "Phase equilibria, thermodynamics and solidification microstructures of Mg-Sn-Ca alloys, Part 1: Experimental investigation and thermodynamic modeling of the ternary $\mathrm{Mg}-\mathrm{Sn}$ Ca system," Intermetallics, vol. 16, no. 2, pp. 299-315, 2008. 
[26] A. Kozlov, M. Ohno, T. A. Leil, N. Hort, K. U. Kainer, and R. Schmid-Fetzer, "Phase equilibria, thermodynamics and solidification microstructures of Mg-Sn-Ca alloys, Part 2: Prediction of phase formation in Mg-rich $\mathrm{Mg}$-Sn-Ca cast alloys," Intermetallics, vol. 16, no. 2, pp. 316-321, 2008.

[27] M. Liu, P. Schmutz, P. J. Uggowitzer, G. Song, and A. Atrens, "The influence of yttrium (Y) on the corrosion of Mg-Y binary alloys," Corrosion Science, vol. 52, no. 11, pp. 3687-3701, 2010.

[28] Y. Ding, Y. Li, J. Lin, and C. Wen, "Effects of zirconium and strontium on the biocorrosion of $\mathrm{Mg}$-Zr-Sr alloys for biodegradable implant applications," Journal of Materials Chemistry B, vol. 3, no. 18, pp. 3714-3729, 2015.

[29] ASTM, "Standard test methods for tension testing of metallic materials," Tech. Rep. E8-04, Annual Book of ASTM Standards, 2004.

[30] ASTM, "Standard test methods for tension testing of metallic materials," Tech. Rep. E8/E8M-13a, ASTM International, West Conshohocken, Pa, USA, 2013.

[31] ASTM, "Standard test methods of compression testing of metallic materials at room temperature," Annual Book of ASTM Standards E9-89a, Annual Book of ASTM Standards, Philadelphia, Pa, USA, 2000.

[32] E. O. Hall, "The deformation and ageing of mild steel: iii discussion of results," Physical Society. Section B, vol. 64, no. 9, pp. 747-753, 1951.

[33] ISO, "Biological evaluation of medical devices. Tests for in vitro cytotoxicity," Tech. Rep. B. 10993-5, 1999.

[34] ASTM, "Standard test methods for determining average grain size,” Tech. Rep. E. 112-96, ASTM International, 2004.

[35] Z. Shi and A. Atrens, "An innovative specimen configuration for the study of Mg corrosion," Corrosion Science, vol. 53, no. 1, pp. 226-246, 2011.

[36] Y. Li, C. Wen, D. Mushahary et al., "Mg-Zr-Sr alloys as biodegradable implant materials," Acta Biomaterialia, vol. 8, no. 8, pp. 3177-3188, 2012. 

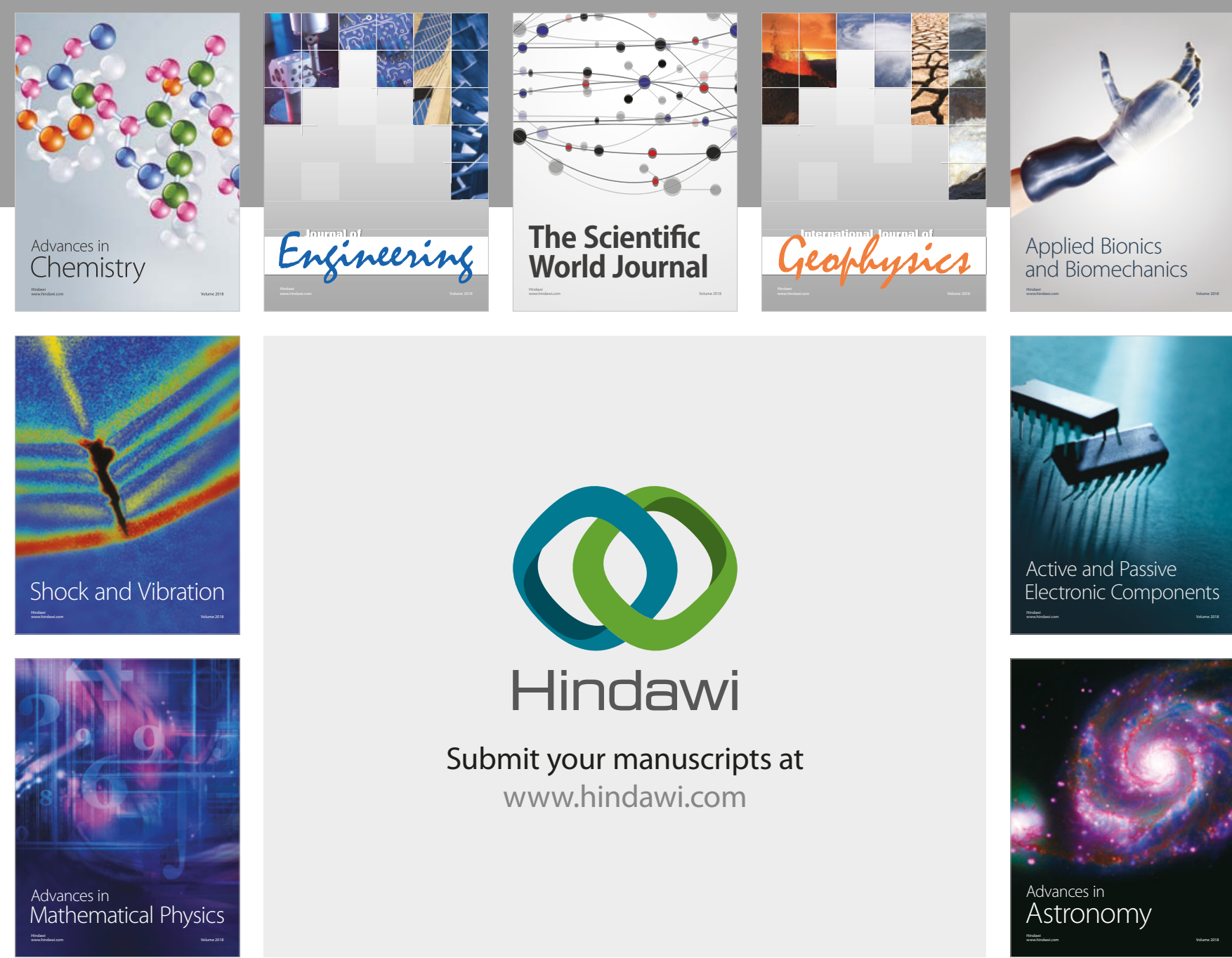

Submit your manuscripts at

www.hindawi.com

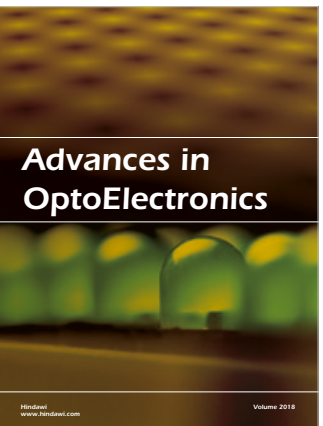

\section{Rotcting Machinery}
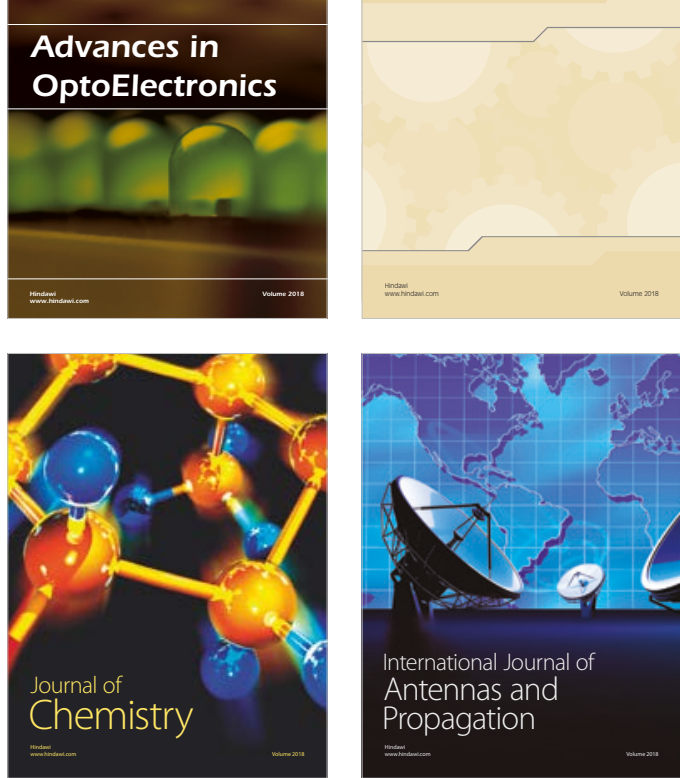

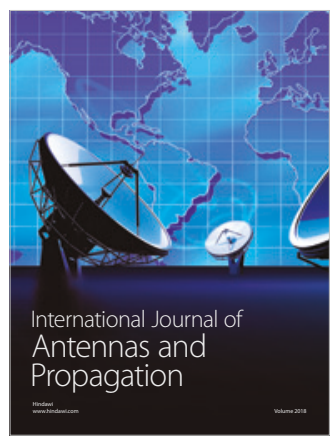

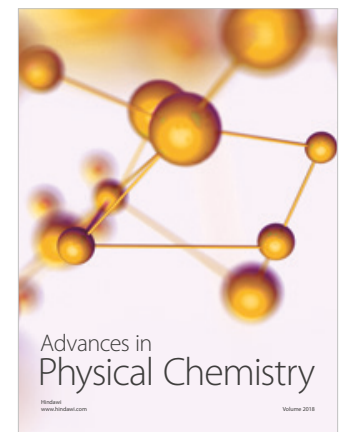

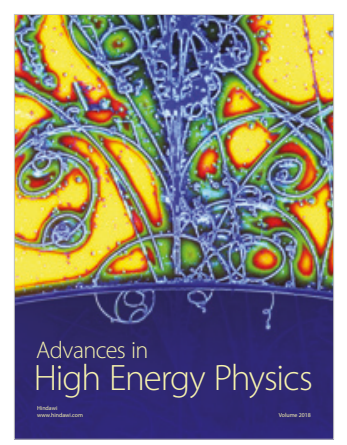

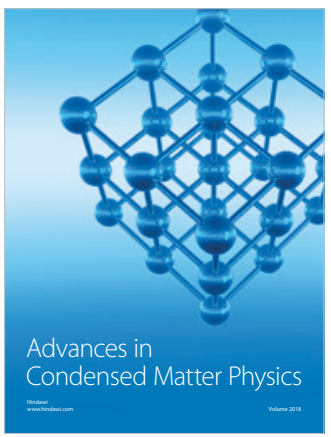

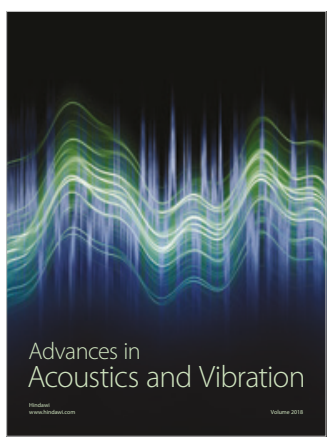

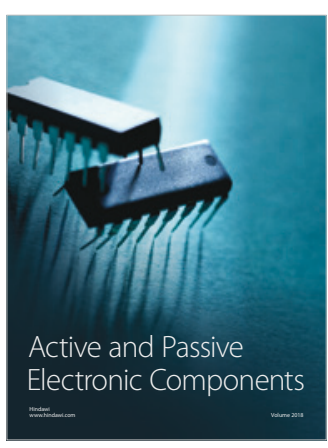
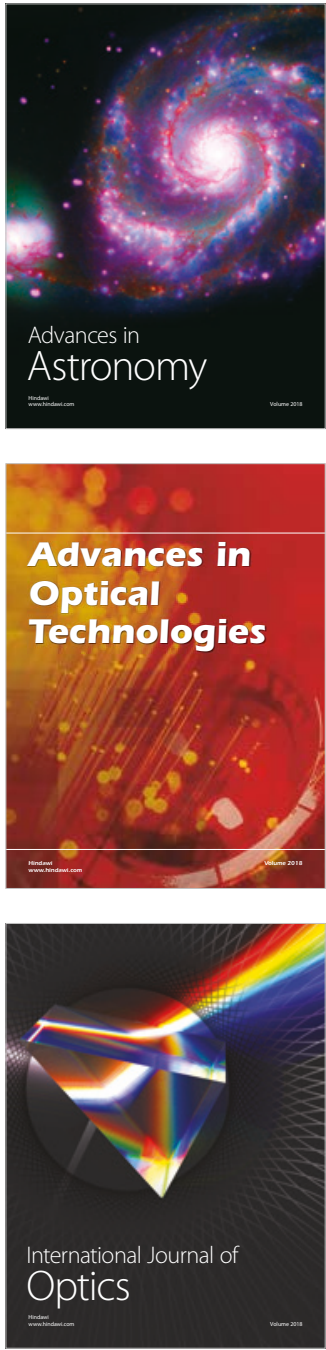